\title{
Reaction of Cobalt-Chromium Casting Alloy with Investment
}

\author{
F. C. ALLAN and KAMAL ASGAR \\ University of Michigan, School of Dentistry, Ann Arbor, Michigan
}

\section{SYNOPSIS IN INTERLINGUA}

Reaction de Alligato Fusional de Cobalt a Chromo con Investimento.-Alterationes chimic occurrente intra le investimento ligate a phosphato durante le prisa e le cocer esseva determinate per technicas a diffraction de radios $\mathrm{X}$. Es postulate le occurrentia de certe reactiones durante le processo. Tests del resistentia al compression effectuate a varie temperaturas corroborava ille postulatos.

Esseva trovate al interfacie inter alligato e investimento tres productos de reaction. Immediatemente adjacente al alligato se formava un scalia de color gris sequite de un intimemente adherente scalia de color verde. Esseva etiam trovate intra le investimento areas de un composito de color rubiastre-brun. Le sonda electronic esseva usate pro analysar iste productos.

Cobalt-chromium alloys have been applied in the field of dentistry as investment castings for partial dentures. These alloys are light, strong, and corrosion-resistant, but the metal does not have adequate ductility for adjustment purposes. Previous research work has shown that one means of obtaining this property is to superheat the alloy before casting. ${ }^{1}$ However, this procedure causes extensive reaction of the metal with the mold and a close-adhering green scale forms. Removal of this scale requires excessive machining, and loss of dimensional accuracy results. As part of a project to improve cobalt-chromium casting alloys, a study was made to find means of minimizing this scale formation.

To analyze the reaction occurring at high temperature, the nature and chemistry of the investment must be known. Work has been done in the ceramic field on many of the compounds present in the investment. Also, in a general way, dental researchers have discussed reactions that may occur. But, the information is scattered and incomplete.

The phosphate-bonded investment was considered in this investigation, since this investment has favorable high-temperature properties and had been used in the previous investigation. ${ }^{1}$ In the phosphate-bonded investments, a soluble phosphate compound

Presented before the Dental Materials Group of the IADR at Toronto, Canada, July, 1965

This investigation was supported by U.S.P.H.S. research grant DE-02017 from the National Institute of Dental Research, National Institutes of Health, Bethesda, $M$ d.

Received for publication Jamuary 7,1966 (e.g., $\mathrm{NH}_{4} \mathrm{H}_{2} \mathrm{PO}_{4}, \mathrm{Mg}\left(\mathrm{H}_{2} \mathrm{PO}_{4}\right)_{2}$, or $\mathrm{H}_{3} \mathrm{PO}_{4}$ ), which produces a phosphate ion, and a metallic oxide (such as $\mathrm{MgO}$ ) form the bond which gives the strength to the investment.

According to Moore and Watts, ${ }^{2}$ the basic reaction causing setting at room temperature is $\mathrm{NH}_{4} \mathrm{H}_{2} \mathrm{PO}_{4}+\mathrm{MgO} \rightarrow \mathrm{NH}_{4} \mathrm{MgPO}_{4}+$ $\mathrm{H}_{2} \mathrm{O}$. This is considered a temporary crystalline bond and is expected to decompose upon heating. Gilham-Dayton ${ }^{3}$ has postulated that the product formed could be di- or trimagnesium phosphate or $\mathrm{NH}_{4} \mathrm{MgPO}_{4}$. $6 \mathrm{H}_{2} \mathrm{O}$. Kiehl and Hardt ${ }^{4}$ have shown that the compound $\mathrm{NH}_{4} \mathrm{MgPO}_{4} \cdot 6 \mathrm{H}_{2} \mathrm{O}$ forms an intermediate hydrate $\left(\mathrm{NH}_{4} \mathrm{MgPO}_{4} \cdot \mathrm{H}_{2} \mathrm{O}\right)$ at about $50^{\circ} \mathrm{C}$. upon heating. Above this temperature, dissociation of the ammonium salt begins, so that by $250^{\circ} \mathrm{C}$. $\mathrm{Mg}_{2} \mathrm{P}_{2} \mathrm{O}_{7}$ forms. Earnshaw ${ }^{5}$ has found experimentally that on heating expansion slows to the point of shrinkage at $100^{\circ} \mathrm{C}$. and attributed this to a loss of water. He also found, "Copious evolution of white fumes occurred in the temperature range $200-260^{\circ} \mathrm{C}$.; at the same time ammonia was also given off." A shrinkage also occurred at temperatures above $280^{\circ} \mathrm{C}$., in his opinion due to chemical reaction.

The bond that exists at high temperatures is attributed to a silicophosphate bond. Tien and Hummel ${ }^{6}$ have formed $\mathrm{SiO}_{2} \cdot \mathrm{P}_{2} \mathrm{O}_{5}$ quite readily by heating $\mathrm{NH}_{4} \mathrm{H}_{2} \mathrm{PO}_{4}$ and silicic acid together and holding at $700^{\circ} \mathrm{C}$. Moore and Watts ${ }^{2}$ have felt that the silicophosphate bond is formed at the $280^{\circ} \mathrm{C}$. temperature.

Another point considered was the green 
TABLE 1

Chemical ANalysis of the Aldoys USED

\begin{tabular}{|c|c|c|c|c|c|c|c|c|c|c|c|c|}
\hline & $\mathrm{Cr}$ & W & $\mathrm{Fe}$ & $\mathrm{C}$ & $\mathrm{Si}$ & $\mathrm{Co}$ & $\mathrm{Ni}$ & $\mathrm{Mn}$ & Mo & B & $P$ & $\mathrm{~S}$ \\
\hline $\begin{array}{l}\text { HS } 21 \ldots \ldots \\
\text { HS } 31 \ldots .\end{array}$ & $\begin{array}{l}27.43 \\
24.81\end{array}$ & 7.54 & $\begin{array}{l}1.67 \\
1.65\end{array}$ & $\begin{array}{l}.27 \\
.48\end{array}$ & $\begin{array}{l}.68 \\
.72\end{array}$ & $\begin{array}{l}\text { Bal. } \\
\text { Bal. }\end{array}$ & $\begin{array}{r}2.51 \\
10.47\end{array}$ & $\begin{array}{l}.69 \\
.78\end{array}$ & $\begin{array}{l}5.45 \\
\ldots\end{array}$ & $\begin{array}{c}>.001 \\
\ldots \ldots\end{array}$ & .016 & .0 \\
\hline
\end{tabular}

scale formed at the interface during casting. Morral* has pointed out that a reaction can be expected at high temperatures when $\mathrm{MgO}$ is used in the investment. Sully ${ }^{7}$ has also discussed problems of mold reaction encountered during casting of chromium alloys and has advised using the highest melting refractory mold materials (e.g., zirconia or thoria). Chromium was found to oxidize quite readily during casting. Work has been done by Phalniker, Evans, and Baldwin ${ }^{8}$ on the oxidation of $\mathrm{Co}-\mathrm{Cr}$ alloys. They have found that the alloy was most resistant when 25 per cent chromium was added to the cobalt, and that selective oxidation of chromium protected the alloy. $\mathrm{CoO}$ was found immediately adjacent to the alloy. Chromium compounds, rather than those of cobalt, occurred at a further distance from the metal surface, indicating a higher diffusivity of the chromium as compared with cobalt. Felten and Gregg ${ }^{9}$ have found the initial oxidation product to be $\mathrm{Cr}_{2} \mathrm{O}_{3}$. Little work other than oxidation of the alloy has been done, and no results have been reported on interface reaction of $\mathrm{Co}-\mathrm{Cr}$ alloys with investment.

In this investigation, the compounds present at the various stages of the mixing and casting procedure were analyzed by $x$-ray-diffraction techniques. To verify the results obtained on the green scale reaction product, samples were also analyzed by the electron probe. By combining the present knowledge with our results from $\mathrm{x}$-ray-diffraction and electron-probe analysis, we propose certain reactions to occur during the investing and casting procedures. Compressive strength tests were then run to test the validity of the reactions.

\section{Materials and Methods}

Phosphate-bonded investments have the following approximate composition: quartz

* F. R. Morral, Cobalt Information Center, personal communication. and cristobalite, 90 per cent; $\mathrm{MgO}, 3$ per cent; acid phosphate, 7 per cent. The selected investment $\uparrow$ was mixed with liquid $\ddagger$ and the following stages were selected for analysis: (1) investment powder, (2) set investment, (3) burned-out investment, (4) green scale formed as reaction product with two casting alloys. $\$$

The compositions of the alloys are given in Table 1.

The powder method of x-ray diffraction was used for analysis. ${ }^{10}$ The samples were ground and passed through a 300-mesh screen. The powder was mixed with cement, $\|$ formed into a rod-like shape, and mounted in the camera. The high silica content limited the extent to which analysis could be carried out, and the silica lines possibly obscured lines of minor constituents which could be present. Separation methods were used in stages 2,3 , and 4 and aided in the analysis. However, some lines were not identified.

To avoid any possible fluorescence, $\mathrm{Cu}$ radiation was chosen as most suitable for analysis of the investment. A Ni filter was used. Since any of the metal could be present in the scale in stage 4 , the use of a $\mathrm{Cu}$ target was questioned. However, very little scatter was found in the results, which would indicate that very little or no Co was present in the green scale.

Microscopic examination has shown three different reaction products occur. The green scale is predominant. A reddish-brown compound also occurs occasionally as discreet nonadhering crystals. The other scale is a gray reaction product, which occurs in a very thin layer (actually, between the green scale and the metal) immediately adjacent

\footnotetext{
† Ceramigold Investment, Whip-Mix Corporation, Louisville, $\mathrm{Ky}$. Ky.

Ceramigold Liquid, Whip-Mix Corporation, Louisville,

$\$$ Haynes Stellite 31 and 21 alloys, Kokomo, Ind.

$\|$ Duco-cement, DuPont, Wilmington, Del.
} 
TABLE 2

Compounds Found DURING X-RAy Diffraction ANALysis

1. Investment powder: $a$-Quartz $a$-Cristobalite

2. Set investment:

$a$-Quartz

a-Cristobalite

$\mathrm{MgO}$

3. Burned-out investment:

$a$-Quartz

a-Cristobalite $\mathrm{MgO}$

4. Formed as reaction product:* $a$-Quartz

a-Cristobalite

$\mathrm{Mg}_{3}\left(\mathrm{PO}_{4}\right)_{2}$
$\mathrm{MgO}$

$\mathrm{NH}_{4} \mathrm{H}_{2} \mathrm{PO}_{4}$

$\mathrm{NH}_{4} \mathrm{H}_{2} \mathrm{PO}_{4}$

$\mathrm{NH}_{4} \mathrm{MgPO}_{4} \cdot \mathrm{H}_{2} \mathrm{O}$

$\mathrm{Mg}_{3}\left(\mathrm{PO}_{4}\right)_{2} \cdot 4 \mathrm{H}_{2} \mathrm{O}$

$\mathrm{Mg}_{2} \mathrm{P}_{2} \mathrm{O}_{7}$

$\mathrm{SiP}_{2} \mathrm{O}_{7}$

$\mathrm{Mg}_{3}\left(\mathrm{PO}_{4}\right)_{2}$

$\mathrm{MgCr}_{2} \mathrm{O}_{4}\left(\mathrm{MgO} \cdot \mathrm{Cr}_{2} \mathrm{O}_{3}\right)$ (most probable) $\mathrm{Cr}_{3} \mathrm{O}_{4}\left(\mathrm{CrO} \cdot \mathrm{Cr}_{2} \mathrm{O}_{3}\right.$ ) (possible)

*No differences were found in the scales formed by the two different alloys.

to the cast metal surface and is intermingled with the investment.

Investment samples containing the reaction products were embedded in methyl methacrylate. ${ }^{*}$ These samples were then polished petrographically until a flat surface of the desired area was obtained. Two different probes were used for the electron probe analysis. One sample analyzed $\dagger$ (Fig. 1) contained the green scale $(A)$ and the reddish-brown compound $(B)$. Scans were run on these two areas and on the investment immediately adjacent to these areas. The other sample analyzed $\ddagger$ (Fig. 2) was of the gray reaction product. These results were obtained as elemental readout.

In order to test whether the silicophosphate bond does indeed form at $280^{\circ} \mathrm{C}$. as

* Castolite, Castolite Company, Woodstock, IIl.

$\uparrow$ Norelco AMR/3 Electron Probe Microanalyzer, Philips Electronic Instruments, Mt. Vernon, N.Y.

$\ddagger$ AMX, Applied Research Laboratories, Glendale, Calif.

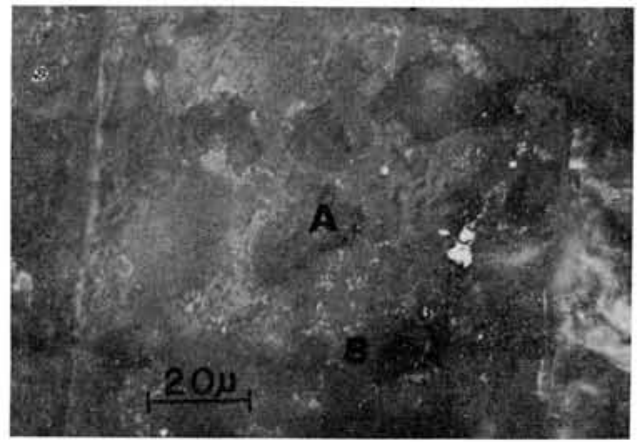

FIG. 1.-Microstructure of areas in the investment analyzed by microprobe: $A$, green scale; $B$, reddish-brown scale. proposed by Moore and Watts, the crushing strength was determined. Three samples were prepared for each temperature. Temperatures were chosen in a step-wise fashion to coincide with possible reaction points, and samples were heated to each of these temperatures and kept at that temperature for 3 hours before they were tested. By this means, the breakdown of the room-temperature bonds also could be followed.

\section{Results}

The compounds that were identified in the various stages are listed in Table 2 . Typical $d$-spacing values are shown in

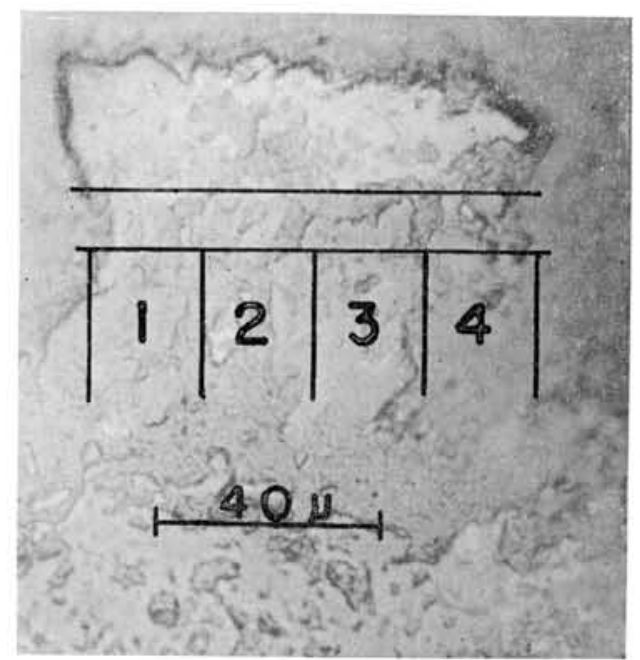

FIG. 2.-Photomicrograph of the investment containing the gray scale. Analysis was made along the area between the two parallel lines. 
TABLE 3

TYPICAL D-SPACING RESULTS

(RUN 1-INVESTMENT POWDER)

\begin{tabular}{|c|c|c|c|c|c|c|}
\hline \multicolumn{2}{|c|}{ Intensity } & \multirow{2}{*}{$\frac{d \text {-Value }}{5.324}$} & $a-\mathrm{SiO}_{2}$ & \multirow[t]{2}{*}{$a-C r i s t o b a l i t e$} & $\mathrm{NH}_{4} \mathrm{H}_{2} \mathrm{PO}_{4}$ & \multirow[t]{2}{*}{$\mathrm{MgO}$} \\
\hline Scat & $\mathrm{M}$ & & & & $5.32 \quad(100)$ & \\
\hline Scat & MS & 4.264 & $4.26 \quad(35)$ & & $\ldots \ldots \ldots$ & \\
\hline Wide & VS & 4.044 & $\ldots \ldots \ldots$ & $4.05 \quad(100)$ & $\ldots \ldots \ldots$ & \\
\hline Scat & $\mathrm{M}$ & 3.786 & $\ldots \ldots$ & $\ldots \ldots$ & $3.75 \quad(64)$ & $\ldots \ldots$ \\
\hline Scat & $W$ & 3.703 & $\ldots \ldots \ldots$ & r & $\ldots \ldots \ldots$ & $\ldots \ldots$ \\
\hline & VVW & 3.447 & & 3.515 & $\ldots \ldots \ldots$ & $\ldots \ldots$ \\
\hline Wide & $\begin{array}{l}\text { VS } \\
M\end{array}$ & $\begin{array}{l}3.357 \\
3.143\end{array}$ & $\begin{array}{c}3.343(100) \\
\ldots \ldots \ldots\end{array}$ & 33135 (11) & $\ldots \ldots \ldots$ & $\ldots \ldots$ \\
\hline Scat & M & 3.102 & $\begin{array}{l}\cdots \\
\cdots \ldots\end{array}$ & $\ldots \ldots$ & $3.075 \quad(89)$ & $\begin{array}{l}\cdots \cdots \\
\cdots \ldots \ldots \\
\cdots\end{array}$ \\
\hline Scat & $\mathrm{M}$ & 3.065 & $\ldots \ldots \ldots$ & $\cdots \cdots$ & $3.065 \quad(75)$ & . \\
\hline Scat & $\mathbf{M}$ & $\begin{array}{l}2.849 \\
2.661\end{array}$ & $\begin{array}{l}\cdots \ldots \ldots \\
\ldots \ldots \ldots\end{array}$ & $\begin{array}{l}2.841 \quad(13) \\
\ldots \ldots \ldots\end{array}$ & $2.659 \quad(18)$ & \\
\hline Scat & $\mathrm{M}$ & 2.641 & $\ldots \ldots$ & & 2.651 (15) & $\ldots \ldots$ \\
\hline Scat & MS & 2.491 & $\ldots \ldots \ldots$ & $2.485(20)$ & $\ldots \ldots \ldots$ & $\ldots \ldots$ \\
\hline Scat & $\mathrm{W}$ & 2.478 & & & & $\cdots$ \\
\hline Scat & MS & 2.463 & $2.458 \quad(12)$ & $2.465 \quad(5)$ & & \\
\hline & W & 2.439 & $\ldots \ldots \ldots$ & $\ldots \ldots \ldots$ & & 2.431 (10) \\
\hline & $W$ & 2.380 & $\ldots \ldots \ldots$ & & $2.373 \quad$ (8) & $\ldots \ldots \ldots$ \\
\hline & VW & 2.337 & & $2.340 \quad$ (1) & $\ldots \ldots \ldots$ & $\ldots \ldots$ \\
\hline & $\mathrm{M}$ & 2.285 & $2.282 \quad(12)$ & $\ldots \ldots \ldots$ & $\ldots \ldots$ & $\ldots \ldots$ \\
\hline & $\mathrm{M}$ & 2.244 & 2.237 & $\ldots \ldots \ldots$ & $\ldots$ & $\ldots$ \\
\hline Scat & M & 2.130 & 2.128 & & $\ldots \ldots$ & \\
\hline & $W$ & 2.122 & $\ldots \ldots \ldots$ & 2.118 & $\ldots \ldots \ldots$ & \\
\hline Scat & MS & 2.110 & $\cdots$ & ${ }_{2} 019{ }^{\cdots}$ & $2000 \quad(20)$ & $2.106(100)$ \\
\hline & $\mathbf{M}$ & 2.013 & & $\ldots \ldots \ldots$ & $2.004 \quad(22)$ & $\cdots$ \\
\hline & M & 1.982 & $1.980 \quad(6)$ & & $\ldots \ldots \ldots$ & $\ldots \ldots$ \\
\hline & W & 1.935 & $\ldots \ldots \ldots$ & $1.929 \quad$ (5) & $\ldots \ldots \ldots$ & $\ldots \ldots$ \\
\hline & W & 1.876 & & 1.870 & $\ldots \ldots \ldots$ & $\ldots \ldots \ldots$ \\
\hline & MS & 1.825 & 1.817 (17) & $\ldots \ldots \ldots$ & $\ldots \ldots \ldots$ & $\ldots \ldots$ \\
\hline & MS & 1.815 & $\ldots \ldots \ldots$ & $\ldots \ldots \ldots$ & & $\ldots \ldots$ \\
\hline & VW & 1.778 & $\ldots$ & $\cdots \cdots \cdots$ & $1.773 \quad$ (5) & $\ldots \ldots \ldots$ \\
\hline & VW & 1.695 & $\ldots$ & 1.690 & & $\ldots \ldots \ldots$ \\
\hline Scat & M & 1.677 & $\ldots \ldots \ldots$ & $\ldots \ldots \ldots$ & $1.685 \quad$ (5) & $\ldots \ldots$ \\
\hline Scat & M & 1.676 & ${ }_{1}{ }_{67} \cdots$ & $\ldots \ldots \ldots$ & 1.677 & $\ldots$ \\
\hline Scat & $\mathbf{M}$ & 1.673 & $\begin{array}{ll}1.672 & (7) \\
1.659 & 3)\end{array}$ & $\cdots$ & $\ldots \ldots \ldots$ & . \\
\hline Scat & $\begin{array}{l}W \\
M\end{array}$ & $\begin{array}{l}1.661 \\
1.541\end{array}$ & $\begin{array}{l}1.0059 \\
1.541\end{array}$ & & & \\
\hline & VVW & 1.533 & $\ldots \ldots \ldots$ & i. 533 & 1.537 & \\
\hline Scat & $\mathrm{M}$ & 1.493 & $\ldots \ldots \ldots$ & 1.494 & $\ldots \ldots \ldots$ & \\
\hline Scat & W & 1.491 & $\ldots \ldots \ldots$ & $\ldots \ldots \ldots$ & & $1.489(52)$ \\
\hline & VVW & 1.474 & $\ldots \ldots \ldots$ & $\ldots \ldots \ldots$ & 1.473 & $\ldots \ldots \ldots$ \\
\hline & W & 1.455 & $i 435 \cdots$ & & 1.470 & \\
\hline $\mathrm{Se}$ - & W & 1.271 & $\begin{array}{l}1.700 \\
\ldots \ldots\end{array}$ & $\cdots$ & $\cdots$ & 1.270 \\
\hline lect- & & 1.217 & $\ldots \ldots$ & $\ldots \ldots \ldots$ & & 1.216 (12) \\
\hline ed & & 1.050 & $\ldots \ldots \ldots$ & $\ldots \ldots \ldots$ & & 1.053 \\
\hline for & & .9421 & $\ldots \ldots \ldots$ & $\ldots \ldots$ & & $.9419(73)$ \\
\hline $\mathrm{MgO}$ & & .8591 & $\ldots \ldots \ldots$ & $\ldots$ & & $.8600(15)$ \\
\hline & & .8107 & $\ldots \ldots \ldots$ & $\ldots$ & . & .8109 (3) \\
\hline
\end{tabular}

Table 3 for the run of the investment powder. Figures 3 and 4 show the probe results obtained on the green area $(A)$ and on the investment adjacent. Figures 5 and 6 show the results for the reddish area $(B)$ and the adjacent investment. A scan was made across the line marked in Figure 7 for each of the elements which could be present in the area shown in Figure 2. These are presented graphically in Figures 8 and 9. Since each run was set for maximum intensity, the height of each reading relates the quantity of that element present. Manganese is not included in the results, since it did not register anywhere in this sample.

The results for the crushing strength tests 


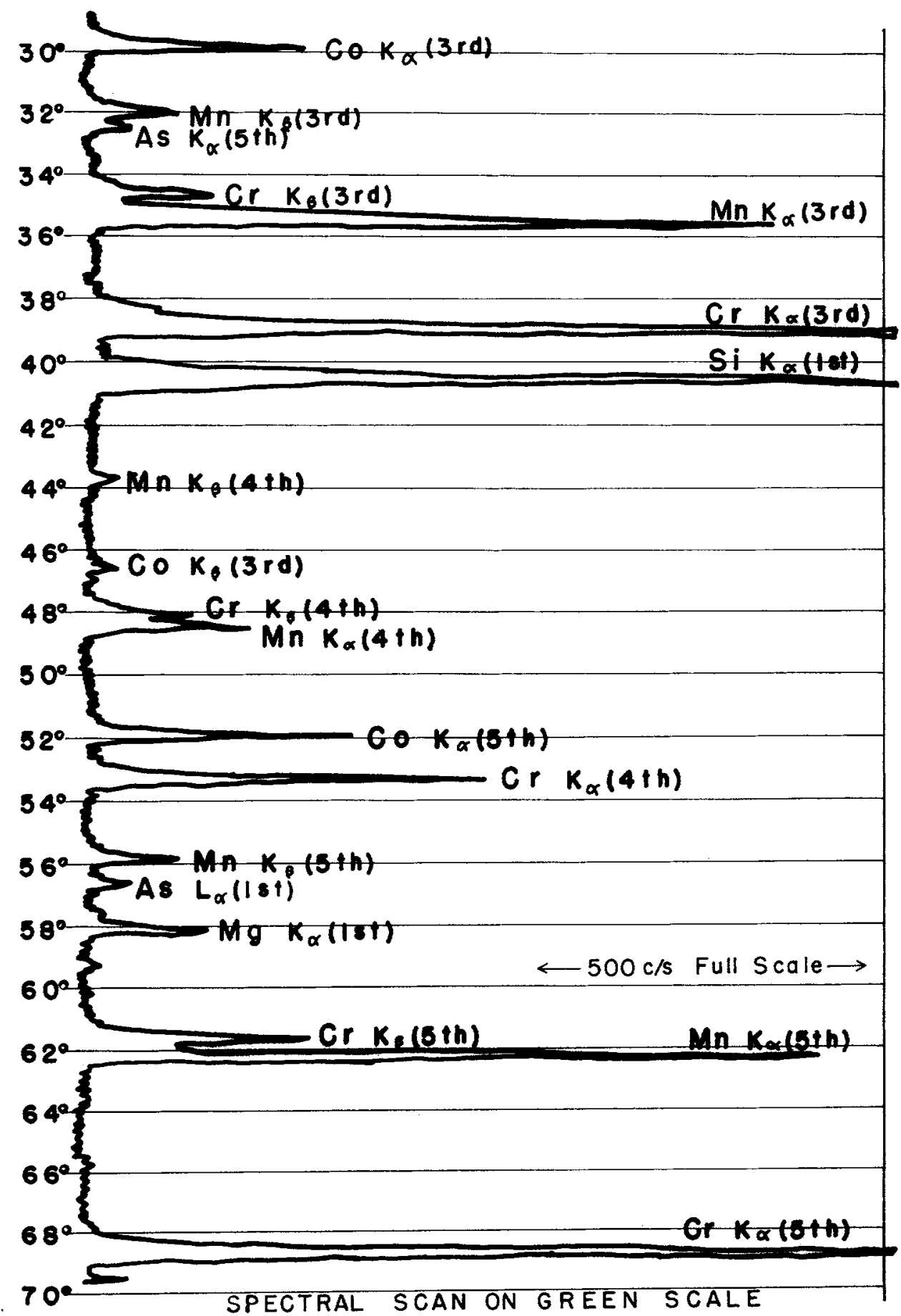

FIG. 3.-Microprobe results for analysis of green scale. 


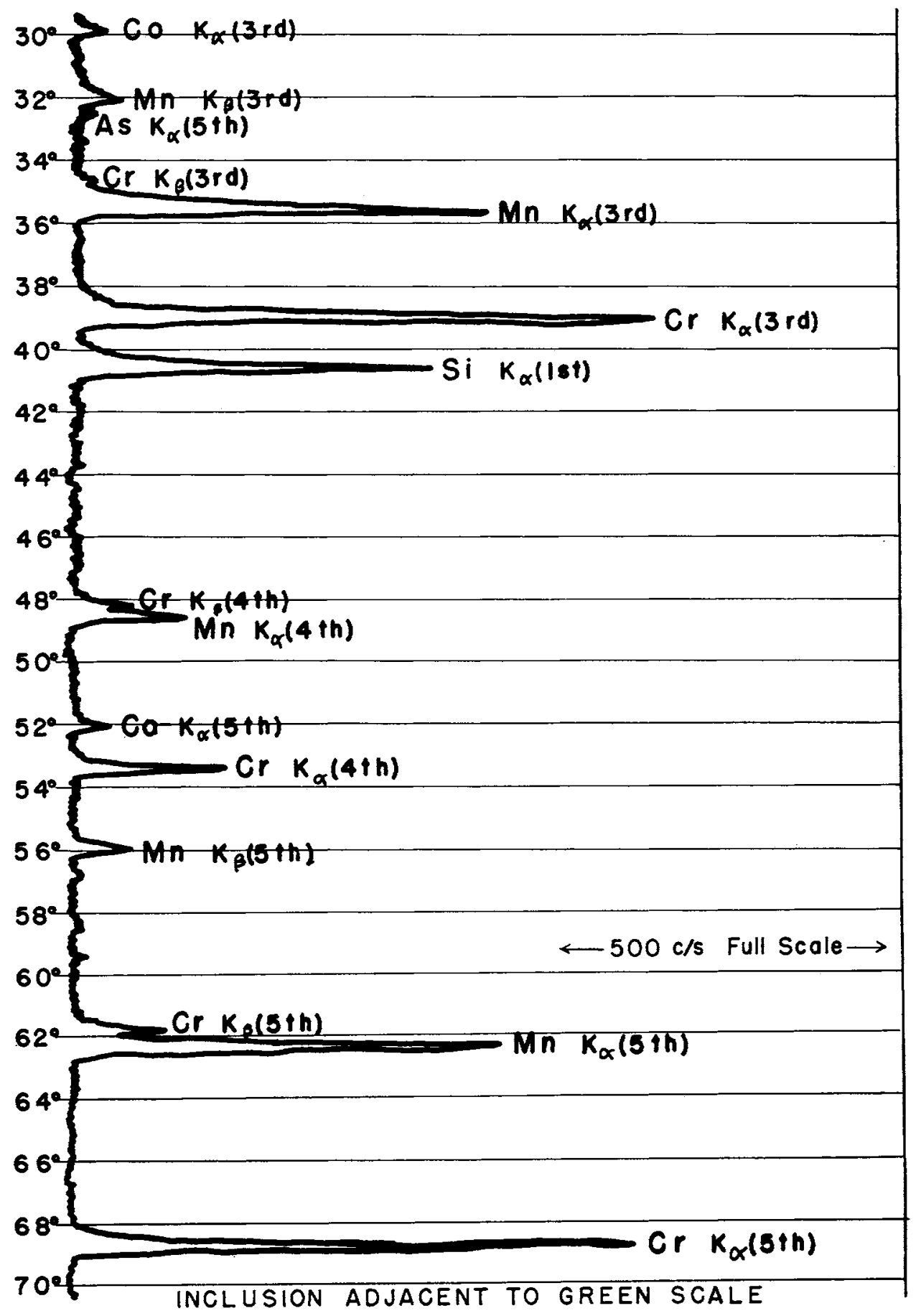

Fic. 4.-Microprobe results for analysis of area adjacent to green scale. 

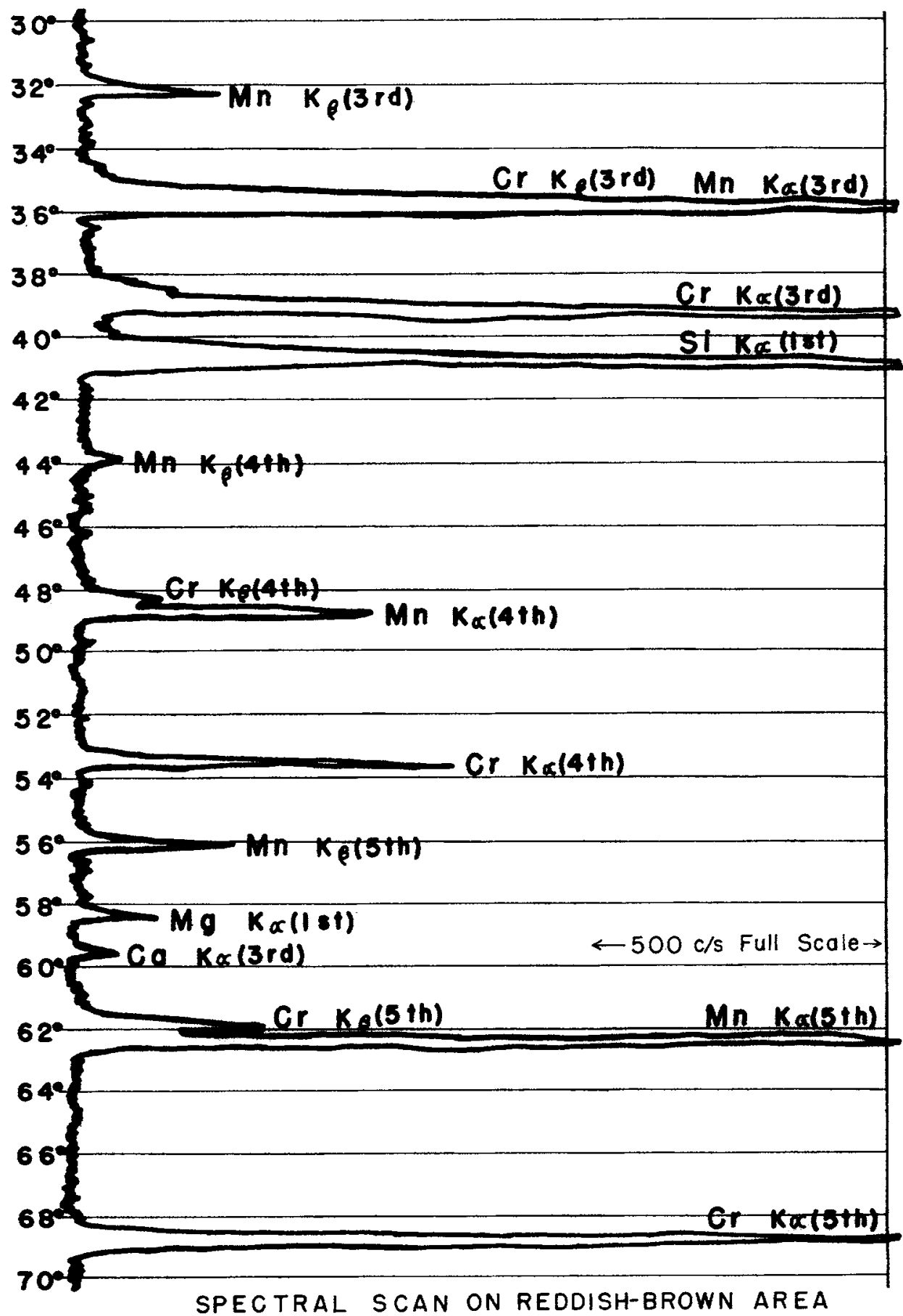

FIG. 5- -Microprobe results for analysis of reddish-brown scale. 


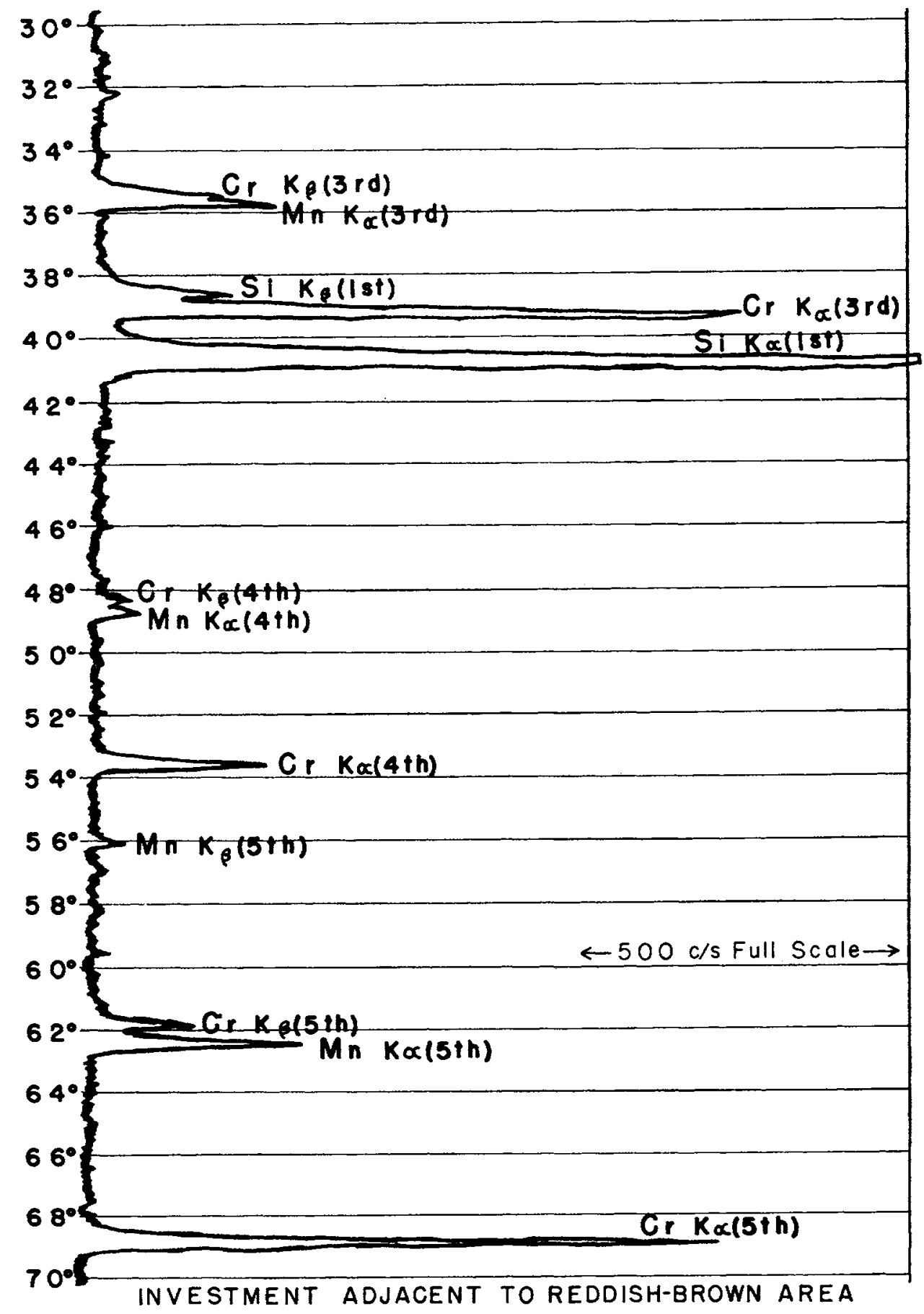

FIG. 6.--Microprobe results for analysis of area adjacent to reddish-brown scale. 
TABLE 4

STRENGTH OF INVESTMENT

\begin{tabular}{|c|c|c|c|c|c|}
\hline $\begin{array}{c}\text { Temperature } \\
\left({ }^{\circ} \mathrm{C} .\right)\end{array}$ & $\begin{array}{l}\text { Compres- } \\
\text { sive } \\
\text { Strength } \\
\text { (p.s.i.) }\end{array}$ & $\begin{array}{l}\text { Stand- } \\
\text { ard } \\
\text { Devia- } \\
\text { tion }\end{array}$ & \multicolumn{3}{|c|}{ Remarks } \\
\hline Room temperature (2 hours). & 1,700 & 40 & \multirow{3}{*}{$\begin{array}{c}\mathrm{NH}_{4} \mathrm{MgPO}_{4} \cdot 6 \mathrm{H}_{2} \mathrm{O} \\
\downarrow \\
\mathrm{NH}_{4} \mathrm{MgPO}_{4} \cdot x \mathrm{H}_{2} \mathrm{O}\end{array}$} & \multirow{3}{*}{$\begin{array}{l}\text { Excess Water } \\
\qquad \mathrm{Mg}_{3}\left(\mathrm{PO}_{4}\right) \cdot 4 \mathrm{H}_{2} \mathrm{O}\end{array}$} & \multirow{6}{*}{$\mathrm{SiO}_{2}+\mathrm{P}_{2} \mathrm{O}_{5}$} \\
\hline Room temperature (6 days).. & 2,100 & 72 & & & \\
\hline $200 \ldots \ldots \ldots \ldots \ldots$ & 2,000 & 85 & & & \\
\hline $250 \ldots \ldots \ldots \ldots \ldots$ & 1,800 & 10 & $\mathrm{Mg}_{2} \mathrm{P}_{2} \mathrm{O}_{7}\left(250^{\circ}\right)$ & \multirow{3}{*}{$\mathrm{Mg}_{3}\left(\mathrm{PO}_{4}\right)_{2} \cdot x \mathrm{H}_{2} \mathrm{O}$} & \\
\hline $300 \ldots \ldots \ldots \ldots \ldots$ & 1,700 & 65 & completed & & \\
\hline $450 \ldots \ldots \ldots \ldots \ldots$ & 2,100 & 65 & & & \\
\hline $500 \ldots \ldots \ldots \ldots \ldots$ & 2,300 & 50 & & \multirow[t]{3}{*}{$\begin{array}{l}\mathrm{Mg}_{3}\left(\mathrm{PO}_{4}\right)_{2} \\
\text { completed }\end{array}$} & $\begin{array}{l}\text { breakdown } \\
\text { of bond }\end{array}$ \\
\hline $1,000 \ldots \ldots \ldots \ldots \ldots \ldots$ & 1,150 & 128 & & & \\
\hline $1,300 \ldots \ldots \ldots \ldots \ldots \ldots$ & 1,600 & 25 & & & fusing \\
\hline $1,400 \ldots \ldots \ldots \ldots \ldots \ldots$ & $3,100+$ & $\cdots$ & fusing & fusing & $\begin{array}{c}\text { extensive } \\
\text { fusing }\end{array}$ \\
\hline
\end{tabular}

are shown in Table 4 . The standard deviations of the compressive-strength values are shown. This table also correlates the reactions, so that compound formation and breakdown can be directly related to the strength at that particular tempera-

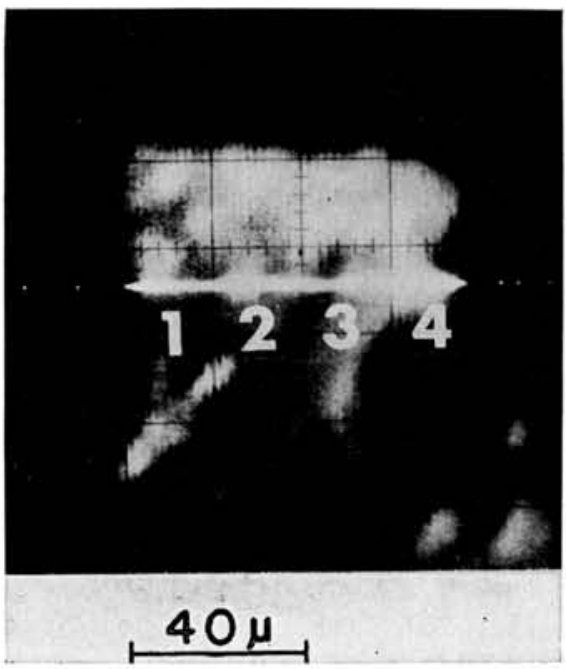

FIG. 7.-Back-scatter pattern of same area shown in Figure 2. Line designates path of electron beam during scans for the elements. ture. The analysis-of-variance results of these strengths at the various testing conditions are shown in Table 5.

\section{Discussion}

The presence of $\mathrm{MgO}$ throughout is attributed to the fact that the compound as received is impure; the manufacturers adjust the amount added to the investment to have a certain percentage of reactive $\mathrm{MgO}$.* The cation

*E. Steinbock, Whip-Mix Corporation, personal communi-

TABLE 5

ANALYSIS OF VARIANCE FOR COMPRESSIVE STRENGTH FOR DIFFERENT CONDITIONS

\begin{tabular}{|c|c|c|c|}
\hline $\begin{array}{l}\text { Source of } \\
\text { Variance }\end{array}$ & $\begin{array}{l}\text { Sum of } \\
\text { Squares }\end{array}$ & $\begin{array}{c}\text { Degrees } \\
\text { of } \\
\text { Free- } \\
\text { dom }\end{array}$ & $\begin{array}{l}\text { Mean } \\
\text { Square }\end{array}$ \\
\hline $\begin{array}{l}\text { Specimens (Columns)... } \\
\text { Experimental Error }\end{array}$ & 712.64 & 9 & 78.07 \\
\hline (Residual) ........... & 15.28 & 20 & 0.764 \\
\hline
\end{tabular}

$F$ of the samples $=78.07 / 0.764=102.1 . F$ for 95 per cent confidence at $N_{1}=9, N_{2}=20$, is given in tables (3.96). (A. J. Duncan, Quality Control and Industrial Statistics, 1955, p. 620.) 
$\mathrm{MgO}$ that remains is unreactive at mixing temperatures, although reactivity may change with temperature increase.

By co-ordinating the literature survey with the results from this investigation the following reactions are proposed. At room temperature during mixing of the investment:

$$
\begin{array}{r}
2 \mathrm{NH}_{4} \mathrm{H}_{2} \mathrm{PO}_{4}+2 \mathrm{MgO}+6 \mathrm{H}_{2} \mathrm{O} \\
\rightarrow \mathrm{NH}_{4} \mathrm{MgPO}_{4} \cdot 6 \mathrm{H}_{2} \mathrm{O}+\mathrm{NH}_{4} \mathrm{H}_{2} \mathrm{PO}_{4} \text { (excess) } \\
+\mathrm{MgO} \text { (unreactive) }+\mathrm{H}_{2} \mathrm{O} .
\end{array}
$$

At $100^{\circ} \mathrm{C}$. expansion slows to the point of shrinkage, probably due to loss of excess water in the mix. Also water loss, starting

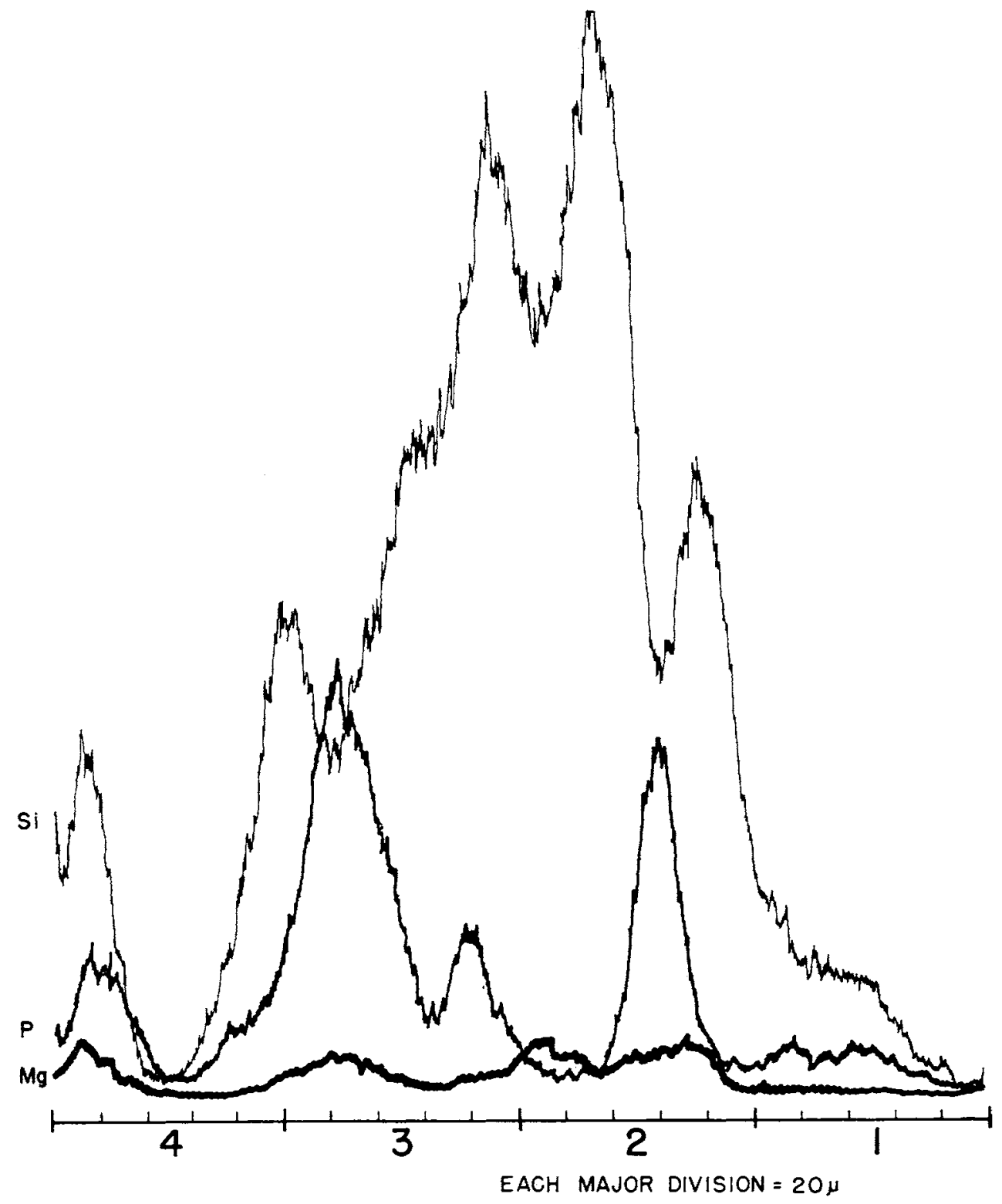

FIG. 8. - Line graphs of investment elements analyzed in Fig 1 re 7. 
at $50^{\circ} \mathrm{C}$, occurs as the hexahydrate is reduced to the monohydrate: ${ }^{4}$

$\mathrm{NH}_{4} \mathrm{MgPO}_{4} \cdot 6 \mathrm{H}_{2} \mathrm{O} \rightarrow \mathrm{NH}_{4} \mathrm{MgPO}_{4}$

$$
\text { - } \mathrm{H}_{2} \mathrm{O}+5 \mathrm{H}_{2} \mathrm{O} \text {. }
$$

At the same time, ammonia also begins to leave the salt. Under equilibrium conditions, the monohydrate converts as follows by $250^{\circ} \mathrm{C}$.:

$$
\begin{aligned}
2 \mathrm{NH}_{4} \mathrm{MgPO}_{4} \cdot \mathrm{H}_{2} \mathrm{O} \rightarrow & \mathrm{Mg}_{2} \mathrm{P}_{2} \mathrm{O}_{7} \\
& +2 \mathrm{NH}_{3} \uparrow+3 \mathrm{H}_{2} \mathrm{O} \uparrow .
\end{aligned}
$$

Although not identified in the $\mathrm{x}$-ray-diffraction results, during setting $\mathrm{Mg}_{3}\left(\mathrm{PO}_{4}\right)_{2}$. $4 \mathrm{H}_{2} \mathrm{O}$ should also form. Upon heating, this compound also loses water:

$$
\mathrm{Mg}_{3}\left(\mathrm{PO}_{4}\right)_{2} \cdot 4 \mathrm{H}_{2} \mathrm{O} \rightarrow \mathrm{Mg}_{3}\left(\mathrm{PO}_{4}\right)_{2}+4 \mathrm{H}_{2} \mathrm{O} \text {. }
$$

Hydrated magnesium phosphate decomposes below $500^{\circ} \mathrm{C}$., which would result in a decrease in bond strength in this range. ${ }^{3}$

At the $200-260^{\circ} \mathrm{C}$. range

$2 \mathrm{NH}_{4} \mathrm{H}_{2} \mathrm{PO}_{4} \rightarrow \mathrm{P}_{2} \mathrm{O}_{5}+2 \mathrm{NH}_{3} \uparrow+3 \mathrm{H}_{2} \mathrm{O} \uparrow$.
The results of the crushing strength tests are shown in Table 4.

The results in Table 5 confirm the validity of the compressive-strength values. Analysis of variance is one of the most powerful tools of statistical analysis. This procedure determines whether the variations in compressive strength were due to actual differences in the specimens or to experimental error. As shown in Table 5, the calculated ratio for means square (102.1) is much larger than the value from the table (3.96); therefore, the differences in compressive strengths of the investment at the various conditions actually occur.

The values decrease in the range where the compounds which give room-temperature strength begin to break down. This is completed by $500^{\circ} \mathrm{C}$. The silicophosphate bond appears to form at a higher temperature than the $280^{\circ} \mathrm{C}$. proposed by Moore and Watts. The strength begins to increase at about $300^{\circ} \mathrm{C}$. By $1,000^{\circ} \mathrm{C}$. the breakdown of this bond is evidenced. By $1,300^{\circ} \mathrm{C}$., as fusing of the constituents begins, the strength again increases. Thus

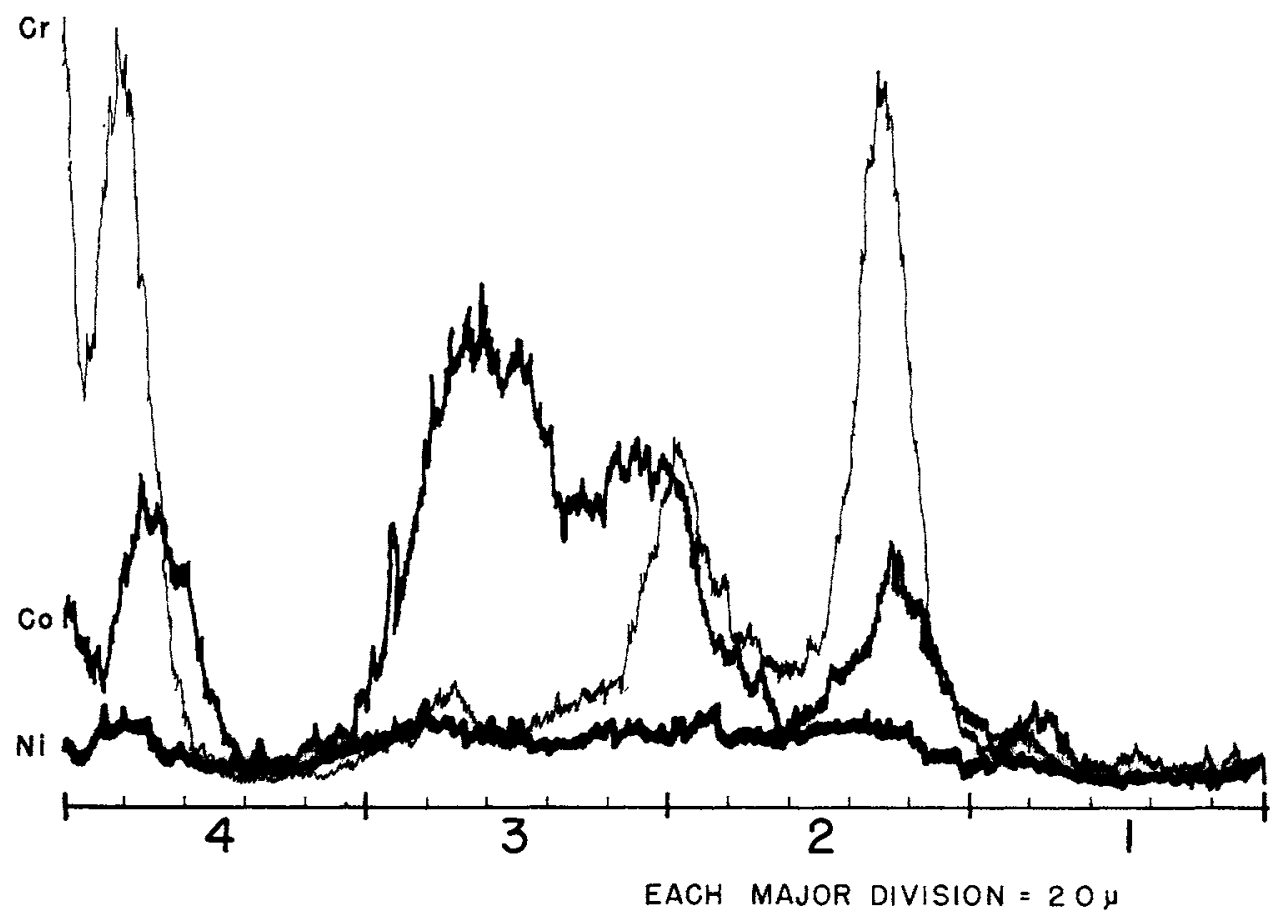

FIG. 9.--Line graphs of alloy elements analyzed in Figure 7. 
magnesia- and silicophosphate compounds and unreacted $\mathrm{MgO}$ and $\mathrm{SiO}_{2}$ are present at the casting temperature. The $x$-ray results indicate that the green scale which forms is $\mathrm{MgCr}_{2} \mathrm{O}_{4}\left(\mathrm{MgO} \cdot \mathrm{Cr}_{2} \mathrm{O}_{3}\right)$ or $\mathrm{Cr}_{3} \mathrm{O}_{4}$. The $\mathrm{MgCr}_{2} \mathrm{O}_{4}$ more closely correlates with the $\mathrm{x}$-ray-diffraction lines. The results were substantially the same for both casting alloys. Probe analysis substantiates this result. Scans of the green scale and of the investment adjacent to the green scale are shown in Figures 3 and 4 . These results are strictly qualitative and give only a general indication of the elements and their amounts present. Since this was a general scan, phosphorus, being a light element, was not determined.

Almost all the elements that exist in the metal and in the investment appear in the green scale analysis. As is shown in Table 1, $\mathrm{Cr}, \mathrm{Co}$, and $\mathrm{Mn}$ are present in the alloy, whereas $\mathrm{Mg}$ and $\mathrm{Si}$ are present in the investment. All of these elements are present in the green scale. $\mathrm{Mg}$ and Si would be expected to appear in greater quantity in the investment. However, the concentration of both $\mathrm{Mg}$ and $\mathrm{Si}$ is greater in the green scale than in the investment immediately adjacent to the green scale. Evidently this investment was depleted of these elements when the green scale formed. Although less than in the green scale, $\mathrm{Cr}, \mathrm{Co}$, and $\mathrm{Mn}$ also appear in the investment in noticeable quantities. Comparison of the occurrence of these metals in Figures 3 and 4 shows that $\mathrm{Cr}$ and Mn have a higher rate of diffusion into the investment than has Co.

The scan on the reddish-brown area did not show the presence of any Co. This could be expected, since none of the thin gray scale has been found adjacent to the reddish areas. $\mathrm{Cr}$ and $\mathrm{Mn}$ were present in large amounts. As occurred in the green scale, $\mathrm{Cr}$ had a high diffusivity and therefore showed in a high concentration on the adjacent investment. Mn in this situation does not diffuse as readily as in the green-scale situation. The presence of the small amount of $\mathrm{Ca}$ is considered as an impurity in the investment. Since this scale appears so sparsely, no analysis was made by $\mathrm{x}$-ray diffraction.

The scans for the gray scale were run differently. Each element was run separately, and the probe was set at maximum intensity for that position.
This method of analysis, then, shows graphically the composition of the investment and gray scale along the line where the beam passed on the specimen. Lines are numbered correspondingly on Figures 2, 7, 8, and 9 . The results showed that the alloy elements are closely approximated in the gray scale and that this scale is a mixture of the cast metal and the investment. However, no Mn was found in either the gray scale or the investment. Therefore, the diffusibility of the Mn must be so great that it passes through the thin gray scale into the green scale. The Co does not appear in too great a quantity considering the high percentage present in the alloy. Cr and Ni coincide with the $\mathrm{Mg}$ and must behave in a manner similar to $\mathrm{Cr}$ in the green scale. Co does not occur closely with any of the investment materials but tends to decrease when the investment materials increase. This probably is the separate oxide $\mathrm{CoO}$ mentioned by Phalniker et al. ${ }^{8}$ and does not combine readily with the investment.

Jackson, Ford, and White ${ }^{12}$ have found that $\mathrm{Cr}_{2} \mathrm{O}_{3}$ wets $\mathrm{MgO}$ quite readily and forms a bond easily. In order to test this conclusion-that oxidation product of the alloy $\left(\mathrm{Cr}_{2} \mathrm{O}_{3}\right)$ is reacting with $\mathrm{MgO}$ in the investment to form an adherent green scale -alloy was cast into a non- $\mathrm{MgO}$ investment (silicate-bonded investment). Although some green scale formed, the quantity was not as great and did not adhere tightly. The surface was much improved.

\section{Summary}

A survey was made of the literature to date in this area. Analysis by $\mathrm{x}$-ray diffraction was used in deriving the reactions occurring during setting and burnout. Crushing-strength tests at various temperatures confirmed these reactions. The reaction product of the alloy with the investment was shown to be $\mathrm{MgCr}_{2} \mathrm{O}_{4}$. It was proposed that with investment containing $\mathrm{MgO}$, excessive heating of the alloy accelerates bonding of the $\mathrm{Cr}_{2} \mathrm{O}_{3}$ to the $\mathrm{MgO}$ grains, producing a scale which is very difficult to remove. Use of a non-MgO investment substantiated this conclusion.

The results for the three different reaction products showed that the thin gray scale formed immediately adjacent to the cast metal surface and contained most of the metal elements. Mn entirely and $\mathrm{Cr}$ par- 
tially diffused rapidly outward and were found in the green scale. To a lesser extent, Co occurred in the same manner, but not in so great a proportion as is found in the original alloy. The reddish-brown areas showed as a reaction of the easily diffusing $\mathrm{Cr}$ and Mn with another constituent of the investment.

\section{References}

1. Asgar, K., and Pevton, F. A. Effect of Casting Conditions on Some Mechanical Properties of CobaltBase Alloys, $J$. dent. Res., 40:73, 1961.

2. MoORE, T. E., and WATTS, C. H. Invesiment Material, U.S. Patent 2,479,504. August, 1949.

3. Grlmam-Dayton, P. A. The Phosphate Bonding of Refractory Materials, Brit. Cer. Soc. Trans., 62:895, 1963.

4. KIEHL, S. J., and HaRdT, H. B. The Dissociation Pressures of Magnesium Ammonium Phosphate Hexahydrate and Some Related Substances III., J. Amer. chem. Soc., 55:605, 1933.
5. Earnshaw, R. Investments for Casting Co-Cr Alloys, Brit. dent. J., 108:429, 1960.

6. TiEN, T. Y., and Hummes, F. A. System $\mathrm{SiO}_{2} \mathrm{P}_{2} \mathrm{O}_{5}$ J. Amer. chem. Soc., 45:422, 1962.

7. Sully, A. H. Chromium, New York, Academic Press, Inc., 1954. pp. 109-24.

8. Phaliniker, C. A., Evans, E. B., and Baldwin, W. M., JR. High Temperature Scaling of CobaltChromium Alloys, J. Electrochem. Soc., 103:429, 1956.

9. Felten, E. J., and Gregg, R. A. The Physical Metallurgy and Oxidation Characteristics of a CobaltBase Superalloy, SM-302, A.S.M. Trans. Quart., 57: $804,1964$.

10. Azarofr, L. V., and Buerger, M. J. The Povder Method in X-ray Crystallography, New York, McGrawHill Book Co., 1958.

11. Duncan, A. J. Quality Control and Industrial Statistics, Homewood, Mll., Richard D. Irwin, Inc., 1955, pp. $431-81$.

12. JACKSON, B., and Ford, W. F., and White, J. The Influence of $\mathrm{Cr}_{2} \mathrm{O}_{3}$ and $\mathrm{Fe}_{2} \mathrm{O}_{3}$ on the Wetting of Periclase Grains by Liquid Silicate, Brit. Cer Soc. Trans., 62:577, 1963. 